\title{
Semiological Analysis of Primary School Students Drawings for "War" Concept
}

\author{
Yelda Usal and İsmail Aytaç
}

\begin{abstract}
Drawing is a sincere and explicative language that children use to reflect their feelings, thoughts, perceptions and observations. Children give clues about their inner world by revealing their perceptions of external world in their drawings. The purpose of this study is to do a semiological analysis of third grade students' visual perceptions of war. The study was carried out with phenomenological pattern. So, the target is to make some inferences from students' drawings. 22 third grade students in Elazig in Turkey participated in the study. After providing them with crayons and papers, these students were asked to draw pictures depicting war. After that, these drawings were analyzed with phenomenological method by the researchers. At the end of the analyses, students made a lot of original, creative and effective drawings depicting war. In these drawings, deep scars of wars taking place in Middle East, where Turkey is geographically and historically close, can be seen. Moreover, there are also some reflections of Turkey's struggle against separatist terrorist organizations in those drawings. The results of the study reveal that children's drawings indicate that there is an atmosphere of distrust and suspicion in the country. In terms of pedagogy, this inference can be made: Children's perceptions and imaginations are shaped largely by topical issues. Television, the internet and printed media are the dominant factors for this shaping.
\end{abstract}

Index Terms-War, drawing, semiotics, visual perception.

\section{INTRODUCTION}

War refers to a comprehensive and a dynamic term which has always been in existence with humanity and which has always changed and become different in terms of method and practice throughout history [1].

Legal rules, which are normative basis of political decisions, aims to solve the disagreements with peaceful means within right and justice measures without resorting to bullying. However, when people, countries or political leaders fail to agree, there emerges war. Whatever its reasons are, war is always tear and blood for everyone and a tragedy for humanity [2]. From the perspective of Turkey, failing of "policy of zero problems with the neighbors" in foreign policy and "resolution process" in domestic policy makes us remember that we are a part of a long-term regional crisis, conflict, war environment. "Polarization" in society is gradually growing. Furthermore, conflicts between civilizations are gradually becoming apparent. Both domestic and external agenda causes the tension on humans to increase Conflicts, fights, violence and war have been our natural agenda [3].

Manuscript received August 9, 2016; revised December 2, 2016.

The authors are with the Firat University Dept of Education, Elazığ, Turkey (e-mail:_yusal@firat.edu.tr, iaytac@firat.edu.tr, iaytac23@hotmail.com).
Today, it is unacceptable to ignore the children's pictures. Us against the image as a privileged tool for understanding the personality, nor it fell exactly what you play for children; the fact that they both play, and fall, as well as reality. "Writing consciously, unconsciously, to portray himself" says Swedish graphologist Pulver. Drawing, never write in a way we can say that we do not dare, because writing has become the standart can be read by anyone who has been standardized; whereas the picture allows greater freedom to the individual. So the picture is quite different from other areas as spatial. People picture, without any coercion, instead he wants to draw the paper. Because it directs him what he drew his "writing is unconscious". There are some basic symbols of our dreams just like in the picture. This can consider symbolic elements as indicators. But when they get it in a context, there is no means alone in this icon. For example, a time window, he drew the rail, where it would not be correct to conclude compliance issues with the child's family. Windows because children have followed in prison the night before a movie and it can be drawn under the influence in different ways. In short, the interpretation of children's picture is extremely complex work, and said it should not be carried out in a haphazard manner can [4].

Semiotics, people, surrounding him inorganic, organic, social, is a science that studies and reading through abstract imagery encrypts the meaning of the universe. Several sets of sign language codes, visual, auditory, verbal or non-verbal communication and all kinds of cultural materials that include indicators for the analysis in terms of the display area is a very rich area in terms of scope and subject department. The founders of semiotics, the feelings of the people, thoughts, ideas, act format, culture, social life, as the ability to handle phrases that displays strings and their solutions [5]. People will see through the form of a significant section of the impressions of the outer perimeter where. Based on this can truly say that it is important for an individual's visual perception for semiotics. Individuals, who have laid siege to the environment color, shape, and saw a lot of bodies confusion, but it must also look at them to see them perceptual sense. Here the individual, begin to perform tasks around the image seen through the clutter by choosing it means that the process starts from the moment of visual perception. However, in the biological sense to see the realization of the visual perception process is not a prerequisite but not sufficient condition. At this point, for the realization of the individual's sense of visual perception process, psychological, or even need to be ready to see an emotional [6].

Wars have affected all activities of mankind. They also affect education systems of countries deeply. Along with this, 
devastation brought by wars demonstrate the value of peace. For this reason, it is possible to see statements about both wars and peace in curriculum. As far as we understand from the literature, it is known that practical issues about wars and peace in United States began immediately after World War One. After World War One, a lot of practical studies were conducted. In

Turkey as well, there are several theoretical and practical studies dealing with wars and peace. In addition, studies dealing with curricula and textbooks are done too [7]. This kind of studies are crucial in order to understand the effects of war on children who live in countries such as Turkey or its neighbors.

\section{METHOD}

\section{A. The Model of the Study and the Working Group}

The purpose of this study is to analyze third graders' perception of war through their drawings. The study, whose method is document analysis, was done in a primary school in Elazig city center in 2015-2016 academic year. Document analysis refers to the process of collecting data via analyzing written documents on certain facts and events [8]. This method is known to be usually used by historians, anthropologists, linguists, sociologists and psychologists. The working group consists of 19 students studying at a primary school in Elazig.

\section{B. Data and Their Analyses}

The data of the study were collected via analyzing students' drawings. A pedagog, an art educator and a sociologist took part in evaluating the drawings. The analyses were done under 4 categories [9]:

1) National Elements Belonging to Turkish Culture; all of the information, beliefs, and behaviors pertaining to a nation and the material objects of these. Language, thoughts, tradition, sign systems (flag, national motifs etc), organizations (Turkish soldiers etc), laws, and tools (guns etc) were evaluated in this category.

2) Slogans and Emphasis on Heroism; In drawings emphasizing heroism, there are emphases on reasonable grounds of war. As to the devastating side of war, the drawings depict hurt brought to humans by wars. Terms like fire, blood, tear, becoming permanently disabled, death were evaluated in this category [7]. Slogans and speech bubbles on the drawings were also taken into consideration while evaluating.

3) Living beings and the colors used; human, animal and plants motifs were taken into consideration while evaluating the drawings.

4) Using war and peace concepts in one context; which concept do the students emphasize: only war, only peace or both? This situation was considered while evaluating the drawings.

\section{FINDINGS AND THEIR INTERPRETATIONS}

In findings section, the drawings were evaluated according to the four categories above. In the chart below, there are percentages of the children, referring to boys as " $\mathrm{B}$ " and girls as "G".

TABLE I: TABLE OF GENDER

\begin{tabular}{|l|l|l|}
\hline Girls & Boys & Total \\
\hline 9 & 10 & 19 \\
\hline
\end{tabular}

TABLE II: DRAWINGS FOR NATIONAL ELEMENTS BELONGING TO TURKISH

\begin{tabular}{|l|c|c|c|}
\multicolumn{1}{|c}{ CULTURE } \\
\hline Flag & Girls & Boys & Total \\
\hline Turkish Soldier & $\% 22$ & $\% 20$ & $\% 21$ \\
\hline Gun & $\% 22$ & $\% 60$ & $\% 42$ \\
\hline $\begin{array}{l}\text { Helicopter-Tank-Milit } \\
\text { ary Vehicle }\end{array}$ & $\% 33$ & $\% 90$ & $\% 63$ \\
\hline
\end{tabular}

In Table II, we can see the percentages of national elements belonging to Turkish Culture depending on the numbers of boys and girls. According to this, boys mostly used guns, helicopters, tanks and military vehicles in their drawings. This situation may stem from the characteristics of their gender. However, we can also see that girls used guns in their drawings more than the other elements. This situation may result from the fact that both visual and social media usually shows images including violence. Moreover, this fact is getting even more severe since both visual and printed media shows images of war and conflicts. The lowest percentage belongs to "flag" for both boys and girls. This situation may indicate that neither children's families nor the education system lay emphasize on national value adequately.

TABLE III: DRAWINGS FOR SLOGANS AND EMPHASIS ON HEROISM

\begin{tabular}{|c|c|c|c|}
\hline & Girls & Boys & Total \\
\hline Slogans & $\% 77$ & $\% 70$ & $\% 73$ \\
\hline
\end{tabular}

Table III present information about percentages of drawings for slogans and emphasis on heroism. According to this table, girls and boys used almost the same amount of slogans and speech bubbles. In the drawings, no emphasis on heroism is seen. The reason of why the students used slogans most is that visual media generally uses this kind of slogans in martyr funerals. When we have a look at the slogans used, we see that they are the ones that we always hear on TV like "Peace in homeland, Peace in the World", "Wars come to an end, and children won't die", "We want peace, not war", " martyrs are immortal our land is indivisible" [4].

TABLE IV: DRAWINGS DEPICTING THE DEVASTATING SIDE OF WAR
\begin{tabular}{|c|c|c|c|}
\hline & Girls & Boys & Total \\
\hline Blood & $\% 11$ & $\% 60$ & $\% 36$ \\
\hline $\begin{array}{c}\text { Tear and } \\
\text { Sadness }\end{array}$ & $\% 33$ & $\% 0$ & $\% 15$ \\
\hline Separation & $\% 33$ & $\% 10$ & $\% 21$ \\
\hline
\end{tabular}

When Table IV is examined, it is seen that the biggest percentage belongs to blood, which was used by boys most. Girls mostly used separation and tears in their drawings. These two situations may stem from the characteristics of their genders.

Table $\mathrm{V}$ provides information about percentages of usage of humans, animals, plants and sun in students' drawings. According to this, all of the students drew human as the one 
who causes wars and experience them.

TABLE V: LIVING BEINGS AND THE COLORS USED

\begin{tabular}{|c|c|c|c|}
\hline & Girls & Boys & Total \\
\hline Human & $\% 100$ & $\% 100$ & $\% 100$ \\
\hline Animal & $\% 22$ & $\% 0$ & $\% 10$ \\
\hline Plant & $\% 44$ & $\% 20$ & $\% 31$ \\
\hline Sun & $\% 33$ & $\% 30$ & $\% 31$ \\
\hline
\end{tabular}

They used plants and animals less. Even though the drawings depict wars, sun takes its place in $\% 30$ of the drawings. When we have a look at the colors used, the most used colors are blue, green and red. Blue and green symbolizes peace and happiness, while red symbolizes blood and Turkish flag. There is also a small amount of orange, yellow, brown, pink, purple and black in the drawings [10].

TABLE VI: DRAWINGS DEPICTING THE WARS AND PEACE TOGETHER

\begin{tabular}{|c|c|c|c|}
\hline & Girls & Boys & Total \\
\hline Only Wars & $\% 33$ & $\% 30$ & $\% 31$ \\
\hline Only Peace & $\% 11$ & $\% 10$ & $\% 10$ \\
\hline $\begin{array}{c}\text { Both Wars } \\
\text { and Peace }\end{array}$ & $\% 33$ & $\% 50$ & $\% 42$ \\
\hline
\end{tabular}

In Table VI, we can see that percentages of girls and boys who depict only wars are almost same. The percentage of students who depict wars are more than the ones who depict peace. The situation shows that they live with wars more than they do with peace in their daily lives (visual and printed media). Boys depict wars and peace together more than the girls do.

\section{DISCUSSION AND RESUlTS}

When we examine students' drawings depicting "war", we can see that they are informed of wars and terrorist attacks that Turkey is exposed to, but still unaware of the seriousness of the situation. More precisely, this situation has not made anything to their psychological states. The reason of this is that they have not experienced war. The fact that flag is not used more shows clearly that national values and peace should be emphasized more in education system. In addition, there are some drawings depicting Syrians who left their hometowns to live somewhere else.

He has not seen war made several pictures of children, but they have made in the usual way; leaving the aircraft bomb on the house or village, soldiers, armies, tanks, explosions, corpses lying on the ground, traces of bullets, shouts (help) and sounds (Bam! Bam!), provincial hospital scene attracts attention [4].

In drawings depicting peace, handshaking is in the foreground. There are very fex drawings depicting captives. While some drawings depict only terrorists, some other depict Turkish soldiers fighting against terrorists.

Wars have damaged both men and women, as well as children. In the drawings, there are crying women and children. Besides, it is understood from slogans that it is the children who are biggest wearies of wars. The drawings depict warplanes dropping bombs, guns firing, and humans lying in a pool of blood.

As a result, as educators, we are supposed to provide present and next generations with training for a long-term peace education. Otherwise, a society who tries to solve its problems via violence and conflicts will go on raising.

According to UNICEF, peace education the process of promoting the knowledge, skills, attitudes and values needed to bring about behavior changes that will enable children, youth and adults to

- prevent conflict and violence, both overt and structural

- resolve conflict peacefully

- create the conditions conducive to peace

Whether at an intrapersonal, interpersonal, intergroup, national or international level. According to Education for all in 1990, peace education should also include necessary knowledge, skills, attitudes and values for an honorable life, along with technical knowledge such as basic education, reading-writing or mathematics. UNICEF alleges that peace education should not only be provided in the countries which experience emergency cases or in state of war, but also in other countries as well. Because, changing a fossilized behavior is possible after a long-term education [3].

Peace education should not only be thought in two-hour course in basic education, but also in every step of curriculum and educational activities of schools.

As a result, we may be angry with someone, or some of us may even dream storming in a tea cup due to "them". but we are supposed to teach peace education to our children. We have to do our best for them. Social peace should be education institutions and educators' first target in their agenda.

\section{REFERENCES}

[1] S. Eker, "Transformation of war case: An example of a new war, and Syria crisis," Turkey Middle East Studies Journal, vol. 2, no. 1, pp. 31-66, 2015

[2] B. Daver. (2015). War and Peace On.

[3] Y. Erdal. (2015). Training programs should be opened in the place of peace $\quad$ education. [Online]. Available: http://www.egitimpedia.com/egitim-programlarinda-baris-egitimine-y er-acilmali/

[4] R. Davido, Discover Pictures of Your Child, İstanbul: Kuraldış1, 2014

[5] Ö. Sayın, Semiotics and Sociology, Ankara: Anı, 2014.

[6] M. İnceoğlu, Attitudes Perception Contact, İstanbul: Beykent Üniversitesi Yayınları, 2010.

[7] Ö. Aktaş, "Meaning of investigation through the art of war and peace concept they install the grade students," Turkish History Education Journal, vol. 4, no. 2, pp. 64-86, 2015.

[8] Z. Karataş, "Qualitative research methods in the social Sciences," Journal of Social Service Research Spiritual Based, vol. 1, no. 1, p. 72, 2015.

[9] Ş. Büyüköztürk, E. K. Çakmak, Ö. E. Akgün, Ş. Karadeniz, and F. Demirel, Scientific Research Methods, Ankara: Pegem, 2014.

[10] S. P. Keskin, Trash Child Secret in Children's Line, İstanbul: Boyut, 2012.

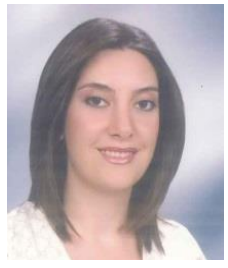

E. Yelda Usal was born in Elazig, Turkey, in 1982 She studied at Vocational College in Firat University in Elazıg in 2000 and she did B.A. degree from Firat University in Elazig in 2008. Then she did MsE degree from Firat University in Elazig in 2012. Usal's major field of study is on art education, graphic and creativity in children. She has been going on doing her PhD degree at art education in Gazi University. 
İsmail Aytaç was born in 1962 in Elazı ̆. He graduated from Selcuk University Faculty of Arts and Sciences. He did his master's degree in 1989 and he received his $\mathrm{PhD}$ on the history of Turkish-Islamic art in1998 at Selçuk University.

He began his career as a lecturer between 1989 at İnönü University Faculty of Education. He opened a large number of personal and group photograph exhibition in the field of art history. He has published many articles. He has been holding the chairman of the department of fine arts at Frat University. Now, he has been holding the presidency of scientific archaeological excavation of Harpt Castle and a member of Council of Sivas Cultural Heritage Protection 